\section{Regeneration of roots and seedlings from Eugenia involucrata seeds under water deficit conditions}

\author{
Mariane Cristina Inocente ${ }^{1 *}$ (D), Claudio José Barbedo ${ }^{1}$
}

ABSTRACT: The aim of this study was to analyze the regenerative capacity of Eugenia involucrata seeds as a possible strategy to ensure the production of new seedlings when they are going through a period of water deficit. Progressive water deficit conditions over time (up to 60 days for seeds and 270 days for seedlings) and in intensity (up to $-5 \mathrm{MPa}$ for seeds and -10 MPa for seedlings) were simulated, and seedling regeneration was analyzed. The results showed that these seeds can survive even under the most extreme conditions (-5 MPa for 60 days) and some seedling tissues as well (-5 MPa for 270 days). Furthermore, roots and seedlings continued to develop from apparently necrotic tissue on the seed surface, showing that, when necessary, these seeds use their mechanism of formation of new roots and seedlings to ensure species survival under water stress conditions.

Index terms: regeneration, water restriction, Myrtaceae, recalcitrant seeds.

\section{Regeneração de raízes e plântulas em sementes de Eugenia involucrata sob déficit hídrico}

RESUMO: Este trabalho buscou analisar a capacidade regenerativa de sementes de Eugenia involucrata como possível estratégia de garantir a produção de novas plântulas quando atravessam período com déficit hídrico. Simularam-se condições de déficit hídrico progressivas em tempo (até 60 dias para sementes e 270 dias para plântulas) e intensidade (até $-5 \mathrm{MPa}$ para sementes e $-10 \mathrm{MPa}$ para plântulas) e se analisou a regeneração de plântulas. Os resultados demonstraram a sobrevivência das sementes mesmo na condição mais extrema (-5 MPa por 60 dias) e de alguns tecidos da plântula (-5 MPa por 270 dias). Também se verificou a continuação do desenvolvimento de raízes e plântulas a partir de tecido aparentemente necrosado em sua superfície, evidenciando que, sob situação de estresse hídrico, quando necessário, essas sementes utilizam seu mecanismo de formação de novas raízes e plântulas para garantir a sobrevivência da espécie.

Termos para indexação: regeneração, restrição hídrica, Myrtaceae, semente recalcitrante.
Journal of Seed Science, v.43, e202143015, 2021

http://dx.doi.org/10.1590/ 2317-1545v43248394 


\section{INTRODUCTION}

The ability to produce new roots and seedlings from fractions of the same seed or cracked seeds has been extensively studied in domesticated species of Eugenia (E. brasiliensis, E. involucrata, E. pyriformis, and E. uniflora) and non-domesticated species (E. candolleana, E. cerasiflora, E. pruinosa, and E. umbelliflora) (Delgado et al., 2010; Amador and Barbedo, 2011; Teixeira and Barbedo, 2012; Amador and Barbedo, 2015; Alonso et al., 2019). Alonso and Barbedo (2020) studied the elimination of successive germinations in whole and fractioned seeds of Eugenia and showed that these seeds are able to produce new roots and seedlings after removal of up to the third root or seedling they produce. Thus, they suggest that this regenerative ability is associated with a strategy of perpetuation of the species in the face of unfavorable environmental conditions.

Inocente and Barbedo (2019) observed germination capacity of some species of Eugenia at water potentials of -0.5 $\mathrm{MPa}$ to $-1.5 \mathrm{MPa}$ and capacity of producing normal seedlings at $-0.5 \mathrm{MPa}$. In addition, when the seeds were under water stress conditions for 60 days and did not germinate, and then transferred to a substrate with water, they germinated and formed normal seedlings. The authors suggest that although Eugenia seeds are intolerant to desiccation, they may have invested in mechanisms which avoid water loss in vital tissues, allowing the germination and development of seedlings when conditions become favorable.

E. involucrata is a tree that is widely distributed in more developed undergrowth in moist soils with not very rugged topography (Legrand and Klein, 1969). Since it does not develop great height and has a broad canopy, it can be used as an ornamental tree (Barbedo et al., 2005). Its seeds are sensitive to desiccation, especially at moisture content lower than $45 \%$ (wet basis), at which point they exhibit a considerable decline both in germination potential and in storage capacity (Barbedo et al., 1998; Maluf et al., 2003; Delgado and Barbedo, 2007). Thus, like seeds of various other species of the same genus, those of E. involucrata also have large capacity for regenerating roots and shoots when part of their reserve tissue is removed; however, these seeds have some control to avoid simultaneous regenerations, so that it is rare that more than one root or shoot can develop at the same time (Silva et al., 2005; Teixeira and Barbedo, 2012). Probably this is a strategy of maintaining diaspores capable of colonizing the environment at different periods through successive germinations (Alonso and Barbedo, 2020). These seeds can germinate even at water potentials as low as $-1.0 \mathrm{MPa}$ and exhibit great tolerance to water deficits. When kept for 60 days at potentials as low as $-3.0 \mathrm{MPa}$, they showed germination superior to $75 \%$ when placed under total availability of water, and more than $30 \%$ of these seeds tolerated water potentials as low as -5.0 MPa (Inocente and Barbedo, 2019).

Considering these mechanisms of preserving water in tissues vital to regeneration and that the formation of new roots and shoots in Eugenia seeds depends on the fractioning or the loss of the first germination, the hypothesis is that water deficit events may also act to induce regeneration of new seedlings. Thus, the aim of this study was to analyze the regenerative capacity of Eugenia seeds as a possible strategy of ensuring production of new seedlings, even when the seed or the seedlings are damaged and the first germination does not result in development of plants through lack of sufficient water availability in the environment.

\section{MATERIAL AND METHODS}

Ripe fruit of Eugenia involucrata DC. was collected in the Fontes do Ipiranga State Park (Parque Estadual das Fontes

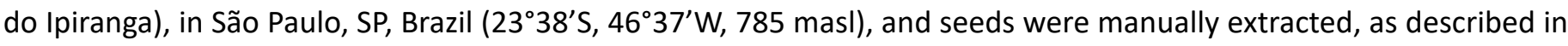
Inocente and Barbedo (2019).

To obtain substrates with different levels of water deficit, aqueous solutions of polyethylene glycol 6000 (PEG) were used at different concentrations. The solutions were prepared based on the calculations and recommendations of Michel and Kaufmann (1973) and assessed in a WP4 dewpoint potentiameter (Decagon Devices, Pullmann, WA, USA), as described in Inocente and Barbedo (2019). Based on previous results that had already shown the great tolerance 
of the seeds of this species to water deficit (Inocente and Barbedo, 2019), the option chosen in this study was to work with solutions that produce water potentials even lower than those used before. Three experiments were performed, as shown in Figure 1 and described below.

Experiment 1: tolerance of germinant seeds to water deficit - E. involucrata seeds were placed to germinate in rolls of paper moistened with water. After the seeds exhibited root emergence of $1.0 \mathrm{~cm}$, hereinafter called germinant seeds, they were transferred to rolls of paper moistened with aqueous solutions of PEG 6000 with osmotic potentials of $-2,-3$, -4 , and $-5 \mathrm{MPa}$, remaining for 30 days. After that, these seeds were washed and returned to rolls of paper moistened with water in four replications of 16 seeds each, which were placed in plastic bags and incubated in a germination chamber at $25{ }^{\circ} \mathrm{C}$ under continuous white-light lighting. Evaluations were carried out weekly, and seeds that had a primary root of at least $2.0 \mathrm{~mm}$ length were considered germinated. The descriptions of Delgado and Barbedo (2012) were followed to obtain the percentage of normal seedlings.

Experiment 2: return to growth of roots and shoots of germinant seeds after progressive water deficit - germinant seeds were sown in rolls of paper moistened with water $(0 \mathrm{MPa})$ or with aqueous solutions of PEG at the osmotic potentials of $-2,-3,-4$, and $-5 \mathrm{MPa}$, for periods of $10,20,30,40,50$, and 60 days. This phase will hereinafter be called incubation in water deficit. At the end of each period, 10-seed samples were removed and transferred to "gerbox" (germination box) type plastic boxes with vermiculite, moistened with water, and kept for 30 days. This phase will hereinafter be called recovery incubation. All the incubations were carried out in a germination chamber with continuous white light at a constant temperature of $25^{\circ} \mathrm{C}$.

At the end of each incubation phase (water deficit and recovery), seeds were counted that had root and/or shoot formation. For the incubation in water deficit phase, the following criteria were used (Figure 2): a) seeds with root

Experiment 1:

"Tolerance of germinant seeds to water deficit"

Seeds placed to germinate up to root with $1.0 \mathrm{~cm}$

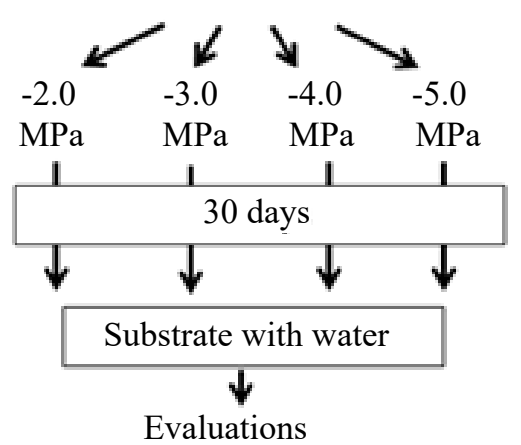

Evaluations

Evaluations

Substrate with water

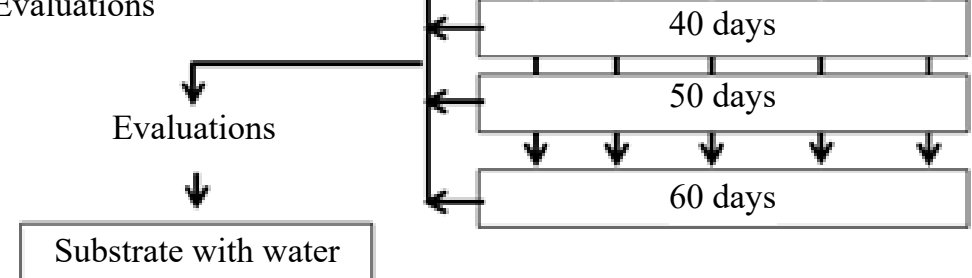

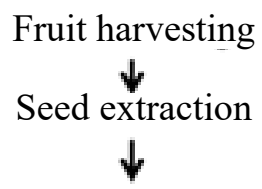

Experiment 2:

"Return to growth of roots and shoots of germinant seeds after water deficit"

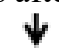

Seeds placed to germinate up to root with $1.0 \mathrm{~cm}$

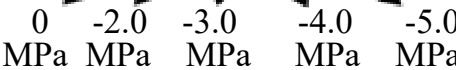

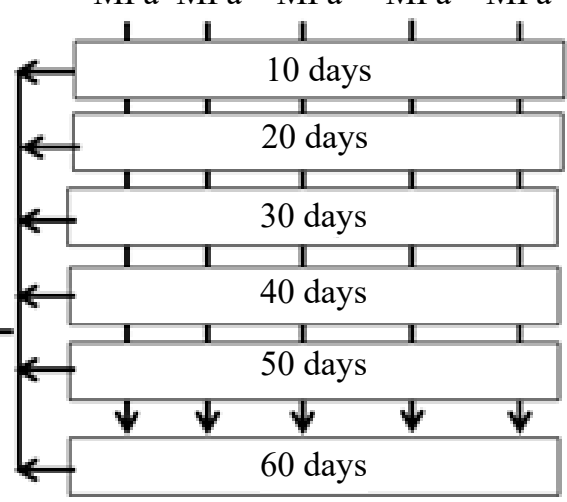

$$
\text { ' }
$$

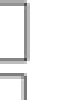


growth and the root is still turgid (NR); b) seeds with root growth and the root has signs of dryness (DR); c) seeds with root and shoot growth and both are turgid (NR/NS); d) seeds with root and shoot growth, the root still turgid and the shoot has signs of dryness (NR/DS); e) seeds with root and shoot growth, the shoot still turgid and the root with signs of dryness (DR/NS); f) seeds with root and shoot growth, root and shoot with signs of dryness (DR/DS). For the recovery incubation phase, the following criteria were used (Figure 3): a) formation of new root without formation of shoot (NR); b) formation of new root and continuation of development of the already existing shoot (NR/TS); c) continuation of development of already existing root and formation of new shoot (TR/NS); d) formation of new root and new shoot (NR/NS); e) formation of new root from the developed structure and formation of shoot from the base of the seed (NROR/NS-S); f) formation of new root from the seed and formation of shoot from the developed structure (NR-S/NS-OS); g) formation of two roots (2NR); and h) formation of two shoots (2NS).

Experiment 3: tolerance of seedlings to water deficit - seeds were placed to germinate in a container with vermiculite moistened with water. Seedlings arising from this sowing that had shoots of approximately $3 \mathrm{~cm}$ were removed and placed in rolls of paper moistened with water (0 MPa) or aqueous solutions of PEG with osmotic potentials of $-1,-2.5,-5,-7.5$, and $-10 \mathrm{MPa}$, in which they remained incubated for 30,60 , and 90 days. At the end of each period, samples were removed to measure root and shoot length, total fresh matter of the seedlings ( $\mathrm{g}$ ), and the number of leaves (units).

The rest remained incubated for 180 days more, for a total of 270 days of incubation. At the end of this period, the seedlings were washed with running water for removal of the PEG residues and divided into two groups. In the first, the shoots and roots were removed, with only the seeds remaining; and in the second, the leaves of the seedlings were removed, with the stem, roots, and the seeds remaining. After that, the material was placed in rolls of paper moistened with water, so as to check for the possibility of new formation of roots and shoots. All the incubations were carried out in a germination chamber with continuous white light at a constant temperature of $25^{\circ} \mathrm{C}$.

The experiments were carried out in a completely randomized design, and analysis of variance was performed on the data ( $F$ test at the level of $5 \%$ ). The experiment regarding seedling tolerance to water deficit used a $6 \times 4$ factorial arrangement (water potential $\times$ incubation period). When pertinent, the mean values were compared to each other by Tukey's test at 5\% (Santana and Ranal, 2004).

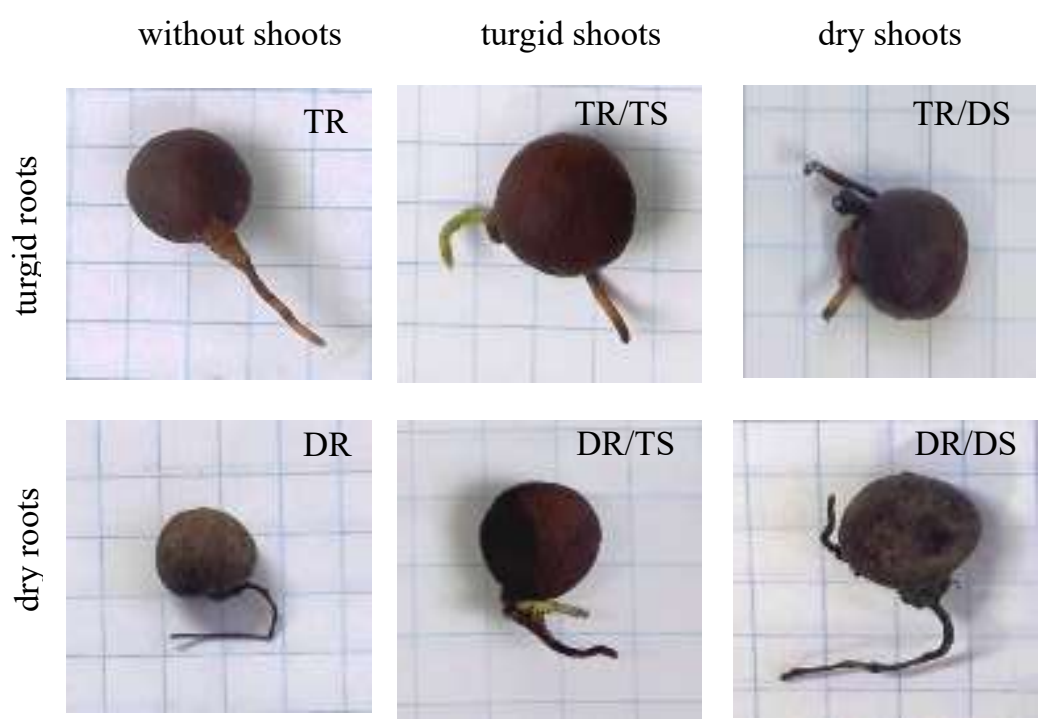

TR: seeds with root growth and the root is still turgid; DR: seeds with root growth and the root already has signs of dryness; TR/TS: seeds with root and shoot growth and both are turgid; TR/DS: seeds with root and shoot growth, the root still turgid and the shoot has signs of dryness; DR/TS: seeds with root and shoot growth, the shoot still turgid and the root with signs of dryness; DR/DS: seeds with root and shoot growth, root and shoot with signs of dryness. Grid square $=5 \mathrm{~mm}$

Figure 2. Characterization of the different growth patterns found in E. involucrata seeds immediately after removal from incubation in substrates with water deficit. 

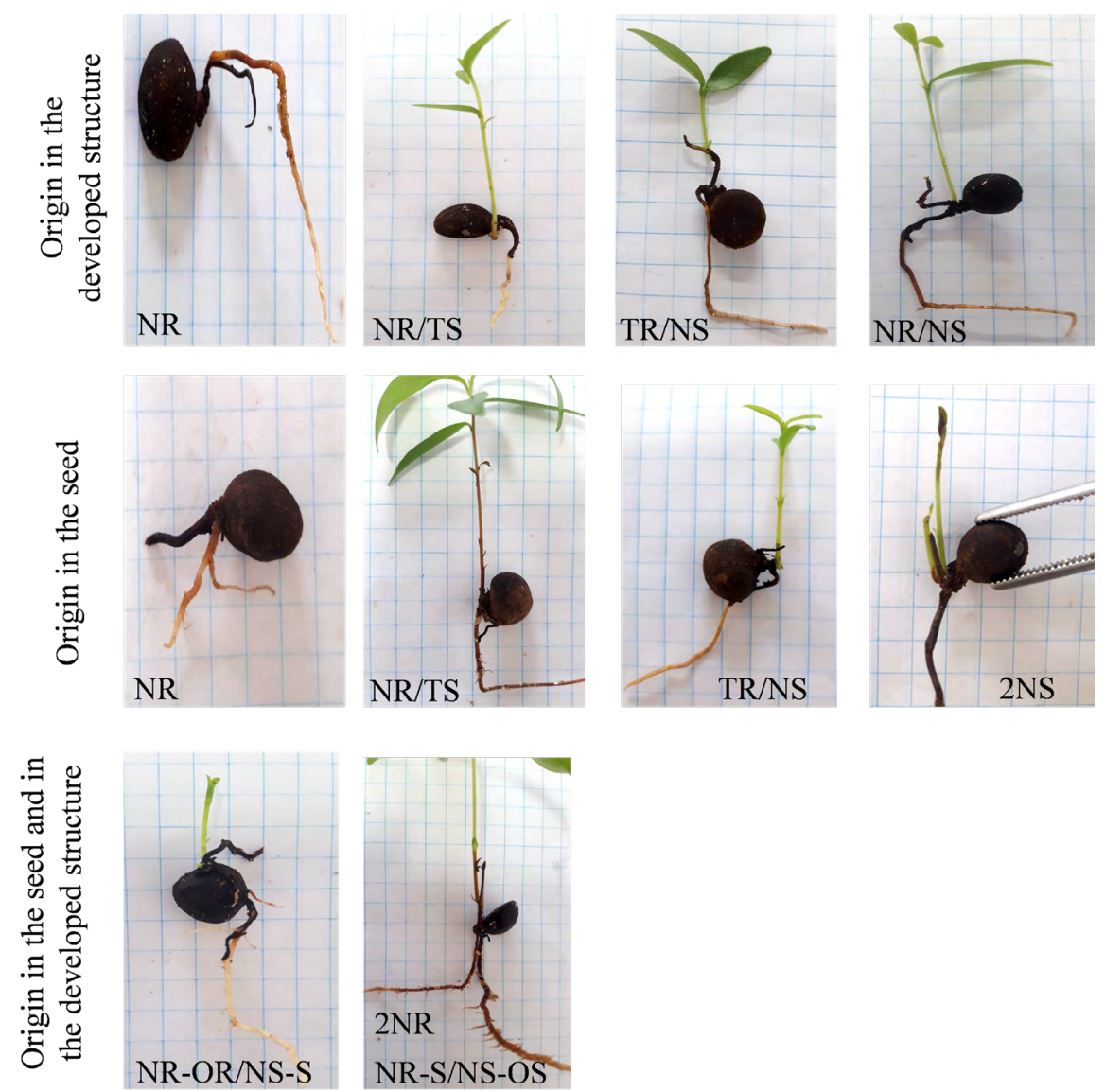

NR: formation of new root without formation of shoot; NR/TS: formation of new root and continuation of development of the already existing shoot; TR/NS: continuation of development of already existing root and formation of new shoot; NR/NS: formation of new root and new shoot; NR-OR/NS-S: formation of new root from the developed structure and formation of shoot from the base of the seed; NR-S/NS-OS: formation of new root from the seed and formation of shoot from the developed structure; 2NR: formation of two roots; and 2NS: formation of two shoots.

Grid square $=5 \mathrm{~mm}$.

Figure 3. Characterization of the different growth patterns found in E. involucrata seeds placed in substrates with water after having been previously incubated in substrate with water deficit. The formation of new roots and shoots was from the seed (when the previously formed structure did not continue growing), from the structure already formed during incubation in the substrate with water deficit, or from both.

\section{RESULTS AND DISCUSSION}

Experiment 1: tolerance of germinant seeds to water deficit - the formation of roots and normal seedlings from seeds incubated for 30 days at different water potentials did not show a difference among the potentials (Figure 4A). However, this formation was wholly a consequence of the structures already existing at the end of incubation at $-5 \mathrm{MPa}$, whereas in those arising from greater water potentials, there was some regeneration of new structures (Figure 4B).

Experiment 2: return to growth of roots and shoots of germinant seeds after progressive water deficit - the exposure to different levels and intervals of water deficit affected formation of roots and shoots in E. involucrata seeds (Figures $5,6$, and 7$)$. In all the water deficit treatments, many primary roots were damaged, turning dark and without turgidity (dry). This was clearest in the 60-day interval and in the -5.0 MPa treatment.

A relationship between the values of the water potential of the substrate and the periodicity of the stress was observed because, in general, the lower the water potential and greater the exposure time to it, the more the seed was affected, increasing the number of root and shoot regenerations, due to the damage caused to the first germination 
(Figure 5). In all the water deficit treatments, the formation of new roots and/or shoots was observed after the seeds were placed in substrate with enough water availability (Figure 6).

A

B
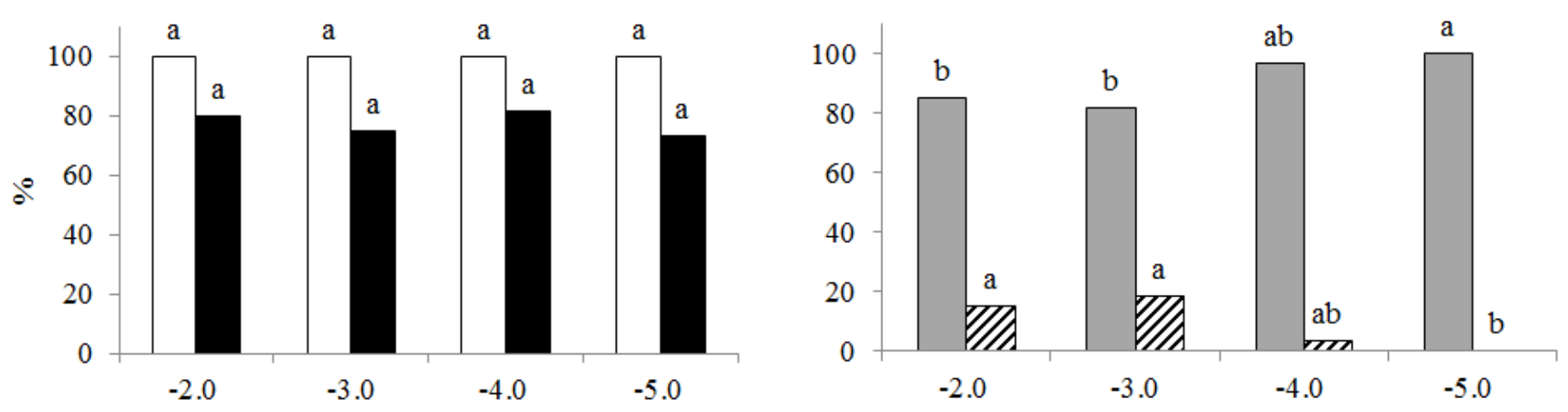

Water potential of the substrate $(\mathrm{MPa})$

Mean values followed by the same letter do not differ from each other for each variable by Tukey's test at $5 \%$.

Figure 4. E. involucrata seeds that formed roots (A, white columns) and normal seedlings (A, black columns) in continuation with already existing structures ( $B$, gray columns) or with formation of new roots and/or shoots (B, striped columns) after incubation at different water potentials (-2.0 to $-5.0 \mathrm{MPa}$ ) for 30 days, followed by maintaining in substrate with water $(0 \mathrm{MPa})$ for 60 days.

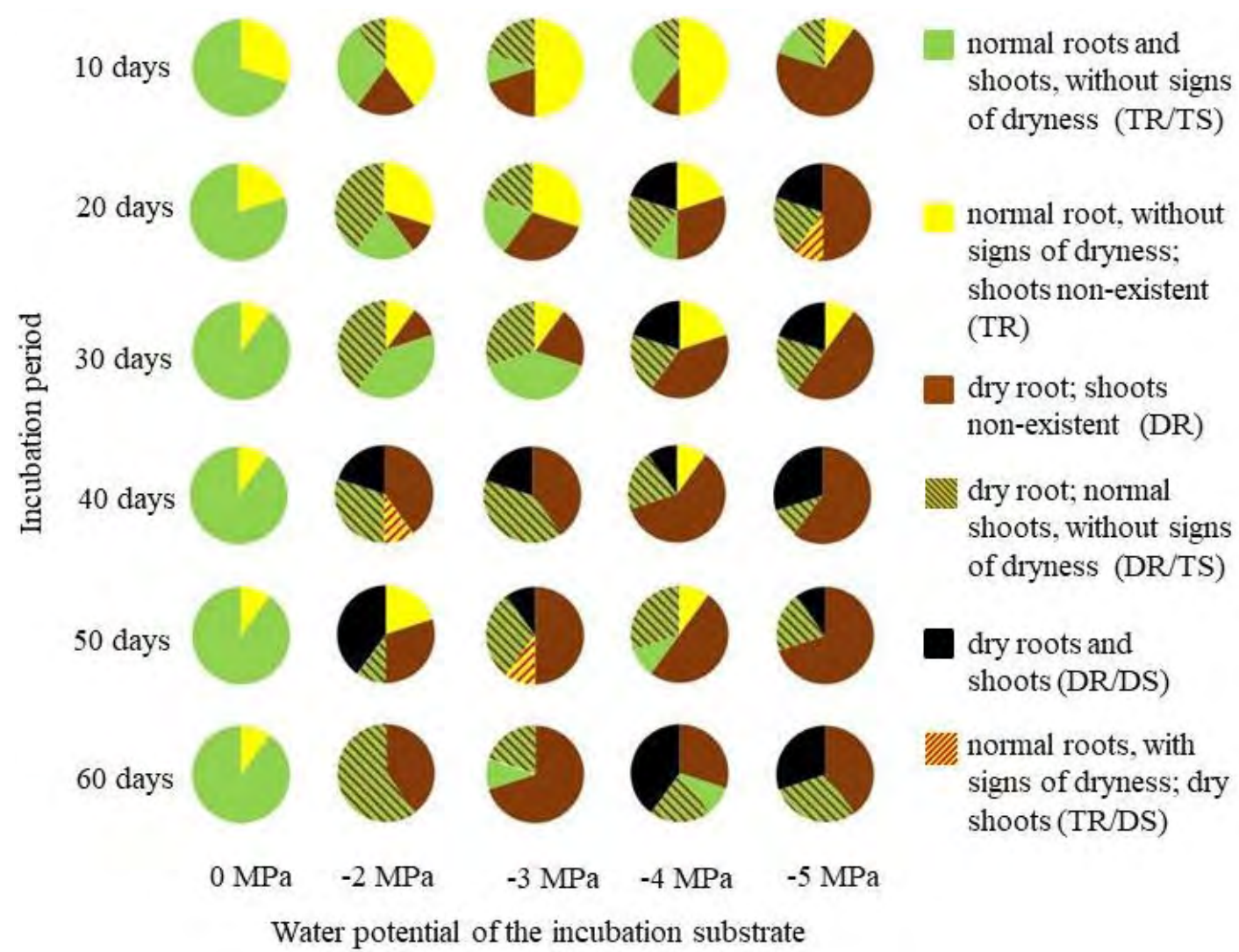

Figure 5. Frequency distribution of different growth patterns found in E. involucrata seeds under different levels $(-2.0$, $-3.0,-4.0$, and $-5.0 \mathrm{MPa}$ ) and intervals (10 to 60 days) of water deficit. For details of the categories, see Figure 1. 


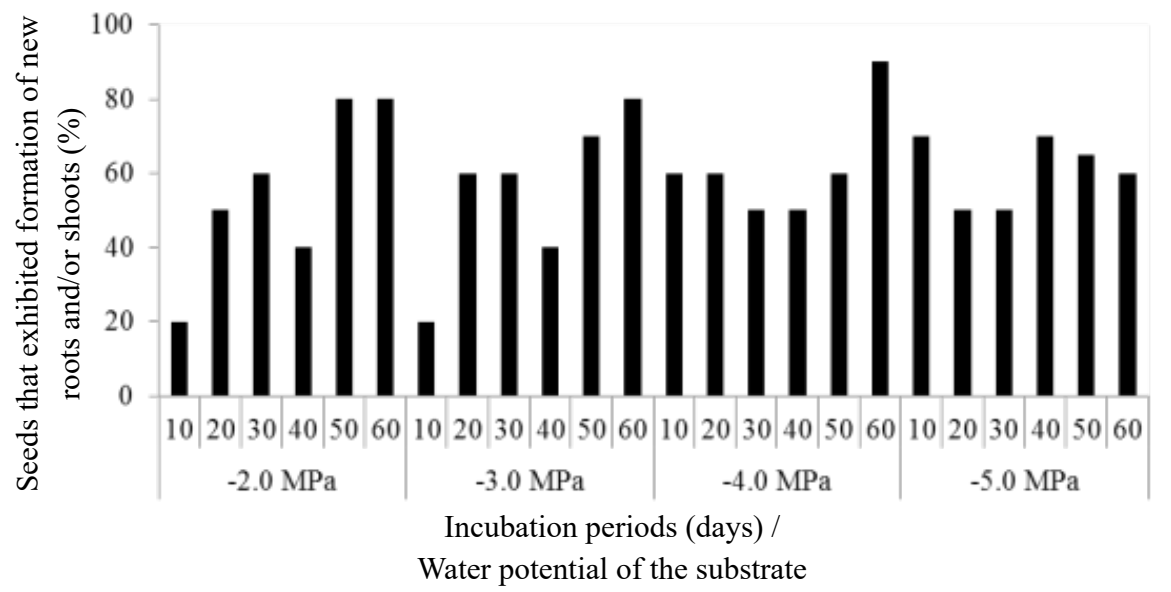

Figure 6. E. involucrata seeds that produced some type of new formation of roots and/or shoots after incubation at different water potentials (-2 to $-5 \mathrm{MPa}$ ) for different periods (10 to 60 days), followed by incubation for 30 days in water.

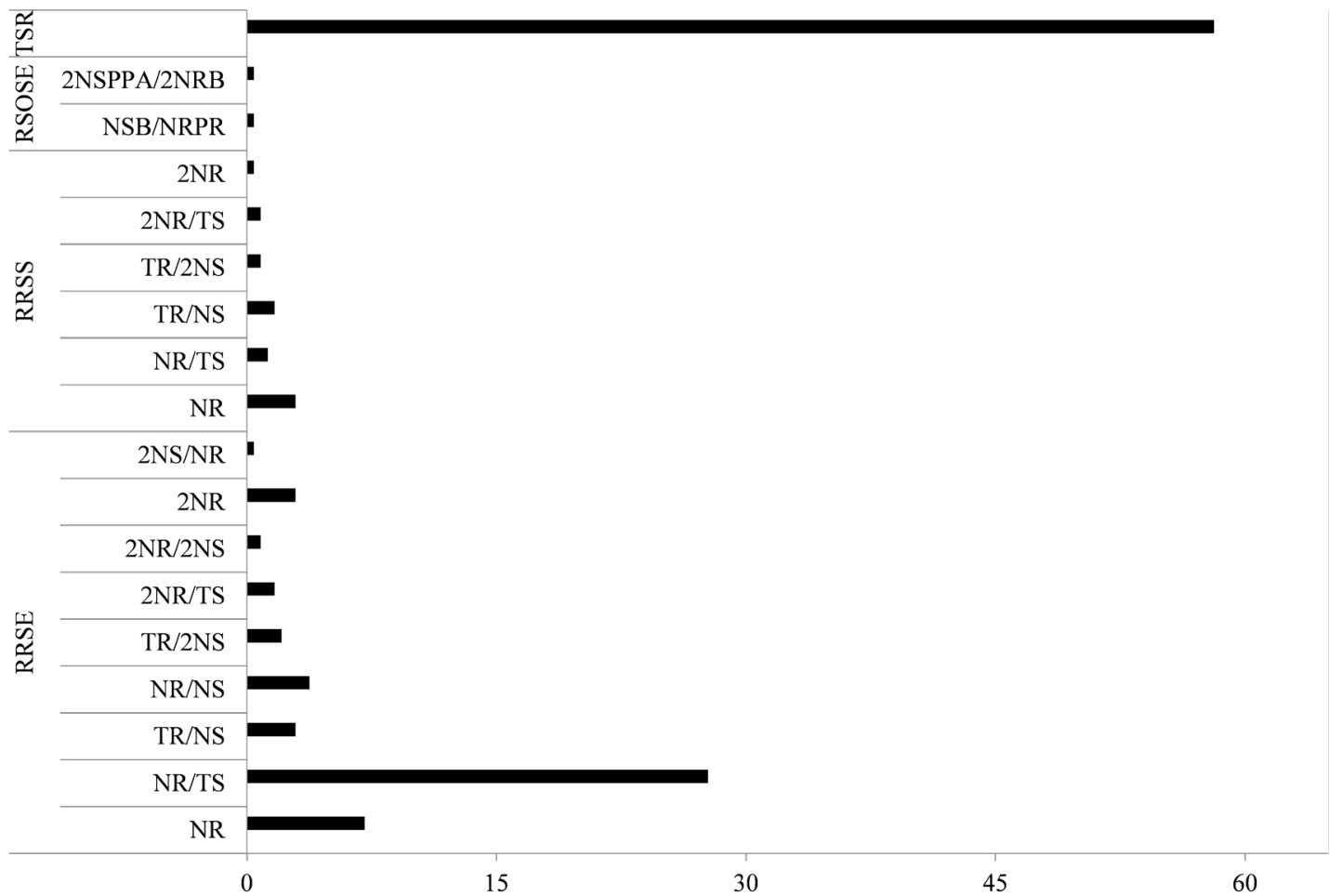

TR: seeds whose first root continued its development normally after its removal from the osmotic solution; NR: seeds whose first root dried out, but that had formation of a new root when removed from the osmotic solution; TS: seeds whose first shoot was formed after removal from osmotic solution or, if formed during incubation in the osmotic solution, it continued its development normally after its removal from this solution; NS: seeds whose first shoot formed dried out, but that had formation of a new shoot when removed from the osmotic solution; 2 NR: the same as NR, but with formation of two roots; 2NS: the same as NS, but with formation of two shoots; RRSE: formation of new roots and/or shoots from the original structures that dried out; RRSS: formation of new roots and/or shoots from the seed; RSOSE: formation of new roots and/or shoots both from the original structures that dried out and from the seed; NSB/NRPR: formation of new shoots as in RRSS, formation of new roots as in RRSE; 2NSPPA/2NRB: 2NS as in RRSE, 2NR as in RRSS; TSR: total seeds that exhibited formation of new roots and/or new shoots after incubation in osmotic solutions, followed by incubation in water.

Figure 7. Frequency distribution of $E$. involucrata seeds that exhibited formation of new roots and/or shoots originating from already existing structures (RRSE), the seed (RRSS), or both (RSOSE) when placed in substrate with water $(0 \mathrm{MPa})$ for 30 days after having been incubated in solutions with water deficit for up to 60 days. 
Experiment 3: tolerance of seedlings to water deficit - up to 90 days of incubation, there was no significant interaction between water potential and incubation period for any of the variables analyzed (Figure 8). There was reduction in the number of leaves, due to leaf abscission, which resulted in reduction in seedling fresh matter.

In the treatments with potentials of -7.5 and $-10 \mathrm{MPa}$, the number of leaves lost was less than in the other treatments, including in the control. The fact that the seedlings developed in another substrate and were then placed in rolls of paper may have affected the loss of leaves, but the lower potentials may have promoted greater conservation of seedling structure. This also may have occurred due to the high viscosity of the solution, resulting from the quantity of PEG 6000 necessary to reach the target water potential (853.189 gPEG.L ${ }^{-1}$ to obtain -7.5 MPa, 989.149 g for -10.0 MPa).

After the period of 270 days under different concentrations of PEG solutions, most of the seedlings showed total leaf abscission; few samples with leaves remained. Some seedlings had withered and wrinkled seeds, and they were discarded. At the water potential of -1.0 MPa, some samples showed regeneration of the shoot or root (Figure 9), which did not occur in the other treatments. After the period of exposure to water deficit and elimination of the first germination, some seeds of Group I previously under as low as -5.0 MPa were able to germinate again when placed in substrate moistened with water (Figure 10A). For Group 2 (Figure 10B), there was no formation of new roots or shoots. In both, there was a high percentage of dead seeds and seeds that did not exhibit regeneration, showing that the long period of exposure to water stress affected seed viability, and few seeds were able to germinate.

Seeds of Eugenia species that have been studied and described in the literature up to now are intolerant to desiccation (Andrade et al., 2003; Maluf et al., 2003; Masetto et al., 2008; Delgado and Barbedo, 2012; Scalon et al., 2012; Calvi et al., 2017a; Silva et al. 2017; Lamarca et al., 2020). Seeds intolerant to desiccation, popularly known as recalcitrant or intermediate seeds, unlike those tolerant to desiccation, called orthodox seeds, do not form a seed bank
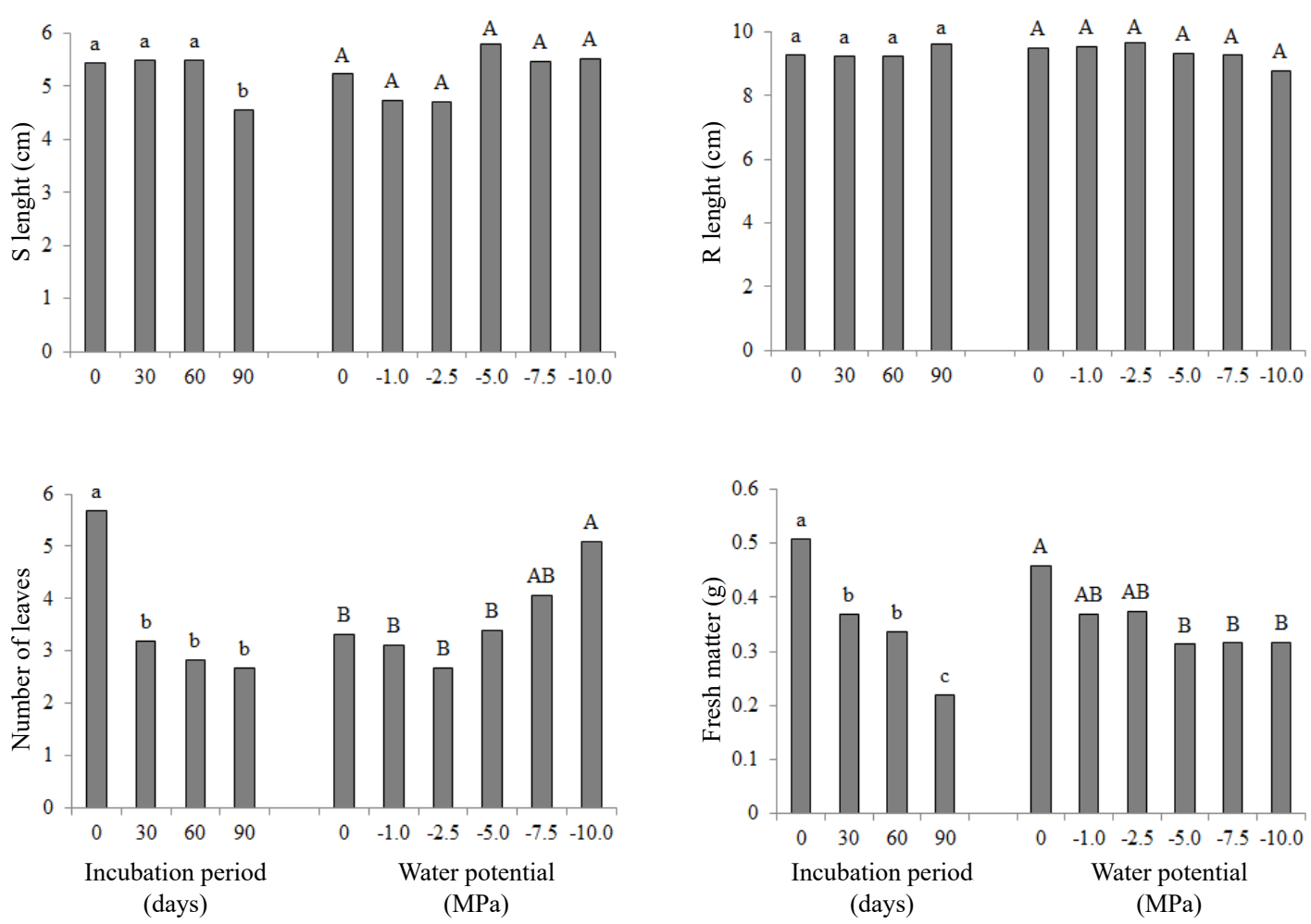

Mean values followed by the same letter (lowercase comparing periods, uppercase comparing water potentials) do not differ from each other by Tukey's test at $5 \%$.

Figure 8. Length of the shoots and roots, number of leaves, and fresh matter of $E$. involucrata plants under different water potentials ( 0.0 to $-10.0 \mathrm{MPa}$ ) for different periods ( 0 to 90 days). 
in the soil (Barbedo and Santos-Junior, 2018). They are dispersed when moisture content is still high and, as they are sensitive to desiccation, they either germinate rapidly or are lost in the environment because they will lose viability either by drying out or by rapid deterioration (Umarani et al., 2015; Barbedo, 2018; Gasparin et al., 2020). However, particularly recalcitrant seeds of Eugenia have shown considerable capacity in ensuring the perpetuation of the species even under adverse conditions of the environment.

Some species of this genus, for example, have shown considerable capacity in tolerating water deficit conditions for the germination and the initial phases of seedling establishment (McLaren and McDonald, 2003; Inocente and Barbedo, 2019), as well as for tolerating flooded conditions (Calvi et al., 2017b). In addition, these seeds can germinate and produce new plants even when a large part of their reserve tissue is lost, for example, through predation (Teixeira and Barbedo, 2012; Alonso et al., 2019; Alonso and Barbedo, 2020; Delgado and Barbedo, 2020).

Particularly in relation to water deficit, Inocente and Barbedo (2019) showed that seeds of Eugenia involucrata, E. brasiliensis, E. pyriformis, and E.uniflora can germinate even in substrate with water potential of $-1.5 \mathrm{MPa}$, which is considered very low for germination of most seeds of agricultural species (Marcos-Filho, 2015). Apparently, when the conditions of the enviroment are favorable to water leaving the seeds of Eugenia species, they begin some process, yet unknown in detail, of preservation of internal water, as seen in the drying process, in which removal of water requires ever increasing time for the same quantity to leave the seed, substantially reducing the values of water potential (Delgado and Barbedo, 2007; 2012). In addition, the seeds that do not germinate under water deficit for up to 60 days can resume germination as soon as water is made available (Inocente and Barbedo, 2019), ensuring an important ecological strategy to pass through drought periods in a way other than the traditional dormancy of orthodox seeds (Barbedo et al., 2013).

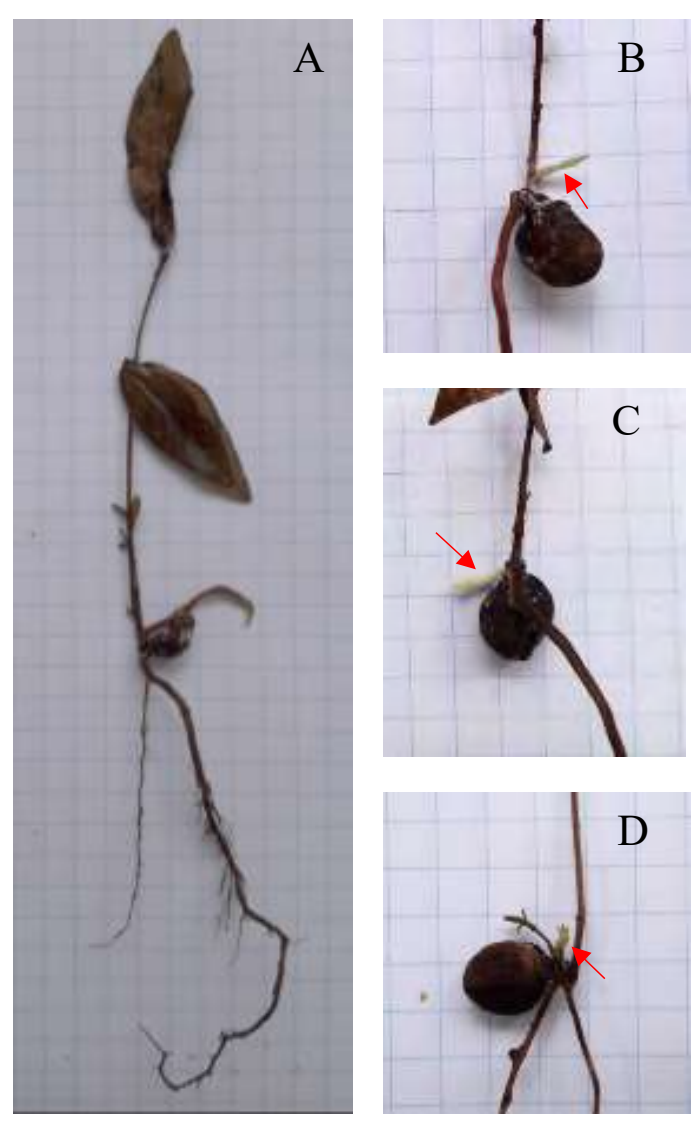

Figure 9. Condition of seedlings at the end of the 270 days of incubation of $E$. involucrata seeds in water deficit (A) and after rehydration $(B, C$, and $D$ ) in which there was regeneration (shown by red arrows) of the shoots and roots. Grid square $=5 \mathrm{~mm}$. 

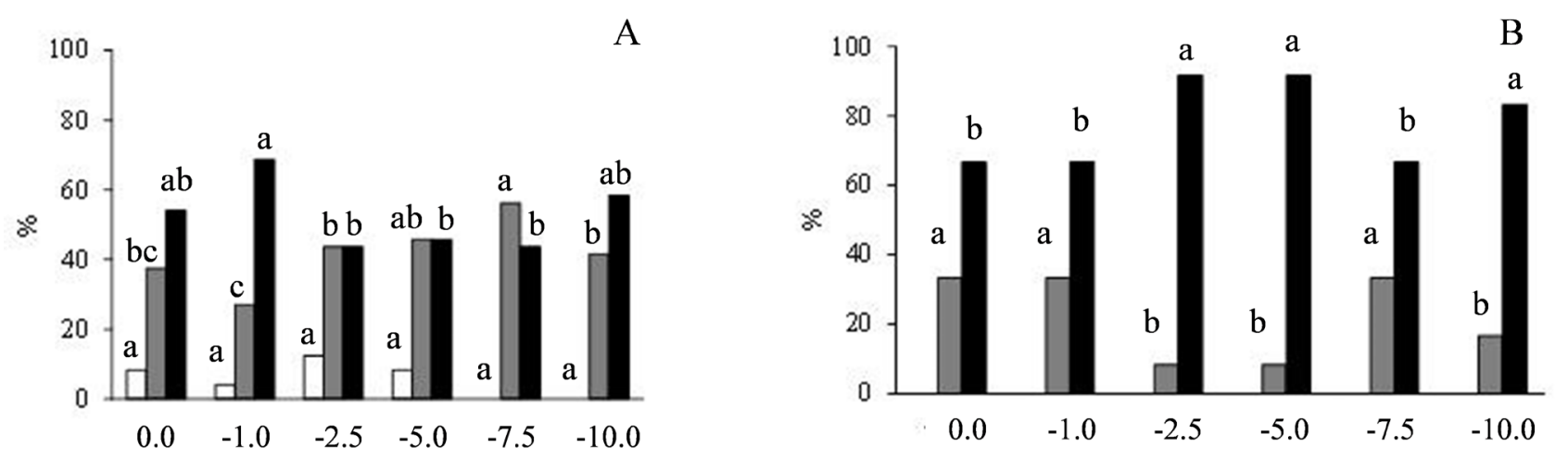

Water potential $(\mathrm{MPa})$

Mean values followed by the same letter do not differ from each other among the water potentials by Tukey's test at $5 \%$.

Figure 10. Percentage of E. involucrata seeds that died (black columns), that did not exhibit visible modifications (gray columns), or that exhibited some type of regeneration (white columns) after incubation in substrate without $(0.0 \mathrm{MPa}$ ) or with different levels of water deficit (-1.0 to -10.0 MPa) for 270 days, followed by incubation in water. In Group 1 (A), at 270 days, roots and shoots were removed, remaining only the seed for incubation in water; in Group 2 (B), only the leaves were eliminated.

The present study showed that for one of the species of Eugenia (E. involucrata), the tools of these seeds to overcome the periods of water deficit are not limited to the seeds before or during their germination but are also in use when water deficit occurs after germination has begun, or in extreme situations, even when the seedling is already developed. The tolerance of germinant seeds and developed seedlings of $E$. involucrata to water deficits was made clear by their ability to form new roots, shoots or even whole seedlings after the death of the first ones, as shown in Figure 4.

Germinant seeds, that is, those in which roots $(1 \mathrm{~cm})$ have already emerged, had good tolerance to substrates with as low as $-5 \mathrm{MPa}$ for 30 days, and, as previously mentioned, this would be quite a severe water deficit, since seeds in general usually do not proceed from phase II of germination at potentials lower than -1.5 MPa. In some cases, there was root formation during incubation in water deficit. When the seeds were returned to substrate with full water availability $(0 \mathrm{MPa})$, some continued the development that occurred during incubation in water deficit, but others whose formed root had a dried-out appearance formed new roots and shoots. It is notable that more than $70 \%$ of the seeds placed under water deficit were able to develop normal seedlings as soon as they were returned to the substrate with available water (Figure 4A), including those coming from incubation in more severe water deficit (-5 MPa).

Another important aspect is that the formation of new structures (that we will here call regenerative capacity), and not the continuation of already existing structures, occurred in the seeds coming from higher water potentials $(-2,-3$ and $-4 \mathrm{MPa}$, Figure $4 \mathrm{~B})$, but not in the lower $(-5 \mathrm{MPa})$. It is possible that in the lighter water deficits $(-2$ and $-3 \mathrm{MPa})$, the seeds advanced more in germination in the period in which they were incubated, as already observed by Inocente and Barbedo (2019), and consequently, they went through greater water deficit in a situation of demand for a larger amount of water to continue the germination process they had achieved. As advanced by Pammenter et al. (1994), hydrated recalcitrant seeds are metabolically active, and some processes, such as extensive vacuolization and increase in cell size, result in the need for water beyond that present in the seed itself.

Thus, recalcitrant seeds exposed to an initially mild water stress that becomes more and more severe could be subject to tissue death. This may explain the need of some seeds having made use of regenerative capacity at higher potentials ( 0 to $-4 \mathrm{MPa}$ ), because they may have advanced more in germination and reached a phase in which there was a greater requirement for additional water. As a result, some seed tissue may have been hurt, activating the known 
regeneration mechanisms of the Eugenia species (Amorim et al., 2020) to produce new roots and/or shoots. However, the great majority of the germinant seeds under 30 days of water deficit did not need to make use of this tool, but were able to continue development of the already existing roots.

When these seeds are exposed for a longer time to water deficit (up to 60 days), some seed tissues are affected by the deficit, and the longer the period of exposure and/or the lower the water potential, the more this occurs (Figure 5). When the structures coming from germination (roots and shoots) are affected by water deficit, the seed makes use of its regeneration mechanisms, which may be either of some part of the affected structures that is still alive or of new original tissue from the seed. Thus, when the deficit does not reach the point of hurting the original tissues, growth continues normally as soon as the water condition is adequate. However, when some part is affected, but live tissues still remain, regeneration occurs from these remaining tissues (Figure 6).

Finally, if even these latter tissues are affected and there is no live structure sufficient for regeneration, even material resulting from the seed itself may be the last resource for regeneration, both for the roots and for the shoots. Frequently, in this period of up to 60 days and at potentials as low as $-5 \mathrm{MPa}$, more than half of the seeds are able to survive water deficit and produce new plants, and the most common result found for the different combinations (Figure 3) was root regeneration, since the first root formed had dried out, and continuation of shoot development for the shoot that did not dry out during incubation under water deficit (Figure 7).

The great tolerance to water deficits showed by roots and shoots raised questions regarding the ability of the plants themselves to exhibit some type of reaction to water deficit, as seen in the following experiment in which seedlings were placed under up to 270 days of exposure to very severe water deficit (-10.0 MPa). In the first 90 days of incubation at these water potentials, little change was seen in root or shoot length, indicating that the seedlings stopped growing (Figure 8). The number of leaves diminished in the first 30 days (Figure 8), which was expected because this leaf loss was visually noted. Interestingly, however, this loss was less at the higher water deficits. The reduction in the number of leaves, associated with an expected and probable loss of water by the moisture conditions of the substrate, led to reduction in seedling fresh matter (Figure 8 ).

At the end of the 270 days of incubation, the seedlings from all the water potentials had a dried-out appearance, as if they were being prepared for dried plant collections (Figure 9A). However, upon returning to the substrate with full water availability $(0 \mathrm{MPa})$, some, surprisingly, once more began regeneration processes of both the roots and shoots (Figures 9B, C, and D). Although these seedlings were in quite a reduced number (Figure 10), it is noteworthy that they appeared to have completely lost the viability of their tissues. Yet, the difference of this response from what are called resurrection plants should be emphasized, because, as such plants are tolerant to desiccation, the very tissues that dry out resume normal activity (Farrant et al., 2020), unlike the result seen in the present study in which the $E$. involucrata seedlings begin to newly sprout from the remaining seed tissues (Figures 9 and 10). Therefore, even seeds that developed seedlings of more than $15 \mathrm{~cm}$ still maintain considerable tolerance to water deficit, bearing up to -10 MPa for up to 90 days and creating a type of blockage to growth, like a type of hibernation. This can continue for up to 270 days and, although roots and shoots die after this period, the remaining seed tissue is still able to regenerate new roots and shoots.

Finally, the results of the present study showed the different tools available to the seeds and seedlings of this species in the face of severe and prolonged water deficits. Initially, these seeds may create mechanisms, not yet identified, of preserving moisture in their tissues that ensures the beginning of germination, as shown by Inocente and Barbedo (2019). In the event of continuity of water deficit after germination has already begun, the innermost tissues of the roots and shoots remain alive, even though the outer tissues do not survive. With the return of adequate water availability to the inner tissues, the development that began may continue, or otherwise, new roots and shoots are possible from the remaining seed tissue. Finally, if the water deficit occurs in an already advanced phase of seedling development, some seeds may have live tissues that are even able to begin sprouting once more and ensure perpetuation of the species. 


\section{CONCLUSIONS}

From the results obtained in the present study, it can be concluded that the capacity of Eugenia involucrata seeds in regenerating roots and seedlings can be an important tool for overcoming periods of water deficit, ensuring the propagation of the species even under unfavorable conditions of the environment. The results also showed that these seeds can tolerate water deficits of up to $-5 \mathrm{MPa}$ for up to 60 days.

\section{ACKNOWLEDGMENTS}

The authors are grateful to the Coordenação de Aperfeiçoamento de Pessoal de Nivel Superior (CAPES) for the Master's degree scholarship granted to the first author, to the Post-graduation Program in Plant Biodiversity and Environment of the Instituto de Botânica for the opportunity of the Master's degree course of the first author, and to the Fundação de Amparo à Pesquisa do Estado de São Paulo (FAPESP) for funding this project (Proc. 2017/50341-0).

\section{REFERENCES}

ALONSO, C.R.; BARBEDO, C.J. Germinações sucessivas em sementes de Eugenia spp. Hoehnea, v.47, e412019, 2020. https://doi. org/10.1590/2236-8906-41/2019

ALONSO, C.R.; ASPERTI, L.M.; GUARDIA, M.C.; BARBEDO, C.J. Cutting and regeneration of roots and seedlings from seeds of Eugenia candolleana DC. at different maturity stages. Journal of Seed Science, v.41, n.2, p.160-167, 2019. http://dx.doi.org/10.1590/23171545v41n2200571

AMADOR, T.S.; BARBEDO, C.J. Potencial de inibição da regeneração de raízes e plântulas em sementes germinantes de Eugenia pyriformis. Pesquisa Agropecuária Brasileira, v.46, n.8, p.814-821, 2011. http://dx.doi.org/10.1590/S0100-204X2011000800005

AMADOR, T.S.; BARBEDO, C.J. Germination inhibits the growth of new roots and seedlings in Eugenia uniflora and Eugenia brasiliensis. Journal of Seed Science, v.37, n.3, p.241-247, 2015. http://dx.doi.org/10.1590/2317-1545v37n3150595

AMORIM, I.P.; SILVA, J.P.N.; BARBEDO, C.J. As sementes de Eugenia spp. (Myrtaceae) e seus novos conceitos sobre propagação. Hoehnea, v.47, e292020, 2020. http://dx.doi.org/10.1590/2236-8906-29/2020

ANDRADE, A.C.S.; CUNHA, R.; SOUZA, A.F.; REIS, R.B.; ALMEIDA, K.J. Physiological and morphological aspects of seed viability of a neotropical savannah tree, Eugenia dysenterica DC. Seed Science and Technology, v.31, n.1, p.125-137, 2003. https://doi. org/10.15258/sst.2003.31.1.13

BARBEDO, C.J. A new approach towards the so-called recalcitrant seeds. Journal of Seed Science, v.40, n.3, p. 221-236, 2018. https://doi.org/10.1590/2317-1545v40n3207201

BARBEDO, C.J.; CENTENO, D.C.; FIGUEIREDO-RIBEIRO, R.C.L. Do recalcitrant seeds really exist? Hoehnea, v.40, n.4, p. 583-593, 2013. https://doi.org/10.1590/S2236-89062013000400001

BARBEDO, C.J.; SANTOS-JUNIOR, N.A. Sementes do Brasil: produção e tecnologia para espécies da flora brasileira. São Paulo: Instituto de Botânica, 2018. 208p.

BARBEDO, A.S.C.; BIANCHI, C.G.; KELLER, L.R.; ORTEGA, M.G.; ORTEGA, S.E.H. Manual técnico de arborização urbana. 2.ed. São Paulo: PMSP-SVMA, 2005. 45p.

BARBEDO, C.J.; KOHAMA, S.; MALUF, A.M.; BILIA, D.A.C. Germinação e armazenamento de diásporos de cerejeira (Eugenia involucrata DC. - Myrtaceae) em função do teor de água. Revista Brasileira de Sementes, v.20, n.1, p.184-188, 1998. https://www. abrates.org.br/files/artigos/58984c45b02322.50920072_artigo30.pdf

CALVI, G.P., AUD, F.F.; FERRAZ, I.D.K.; PRITCHARD, H.W.; KRANNER, I. Analyses of several seed viability markers in individual recalcitrant seeds of Eugenia stipitata McVaugh with totipotent germination. Plant Biology, v.19, n.1, p.6-13, 2017a. https://doi. org/10.1111/plb.12466 
CALVI, G.P.; ANJOS, A.M.G.; KRANNER, I.; PRITCHARD, H.W.; FERRAZ, I.D.K. Exceptional flooding tolerance in the totipotent recalcitrant seeds of Eugenia stiptata. Seed Science Research, v.27, p.121-130, 2017b. https://doi.org/10.1017/S0960258517000125

DELGADO, L.F.; BARBEDO, C.J. Tolerância à dessecação de sementes de espécies de Eugenia. Pesquisa Agropecuária Brasileira, v.42, n.2, p.265-272, 2007. https://doi.org/10.1590/S0100-204X2007000200016

DELGADO, L.F.; BARBEDO, C.J. Water potential and viability of seeds of Eugenia (Myrtaceae), a tropical tree species, based upon different levels of drying. Brazilian Archives of Biology and Technology, v.55, n.4, p.583-590, 2012. https://doi.org/10.1590/S151689132012000400014 .

DELGADO, L.F.; BARBEDO, C.J. Regeneração de raízes e plântulas de sementes de Eugenia spp. (Myrtaceae) de diferentes estádios de maturação. Hoehnea, v.47, e042020, 2020. http://dx.doi.org/10.1590/2236-8906-04/2020

DELGADO, L.F.; MELLO, J.I.O.; BARBEDO, C.J. Potential for regeneration and propagation from cut seeds of Eugenia (Myrtaceae) tropical tree species. Seed Science and Technology, v.38, n.3, p.624-634, 2010. https://doi.org/10.15258/sst.2010.38.3.10

FARRANT, J.M.; MOORE, J.P.; HILHORST, H.W.M. Editorial: Unifying insights into the desiccation tolerance mechanisms of resurrection plants and seeds. Frontiers in Plant Science, v.11, p.1-3, 2020. https://doi.org/10.3389/fpls.2020.01089

GASPARIN, E.; FARIA, J.M.R.; JOSÉ, A.C.; TONETTI, O.A.O.; MELO, R.A.; HILHORST, H.W.M. Viability of recalcitrant Araucaria angustifolia seeds in storage and in a soil seed bank. Journal of Forest Research, v.31, n.6, p.2413-2422, 2020. https://doi.org/10.1007/s11676019-01001-z

INOCENTE, M.C.; BARBEDO, C.J. Germination of Eugenia brasiliensis, E. involucrata, E. pyriformis, and E. uniflora (Myrtaceae) under water-deficit conditions. Journal of Seed Science, v.41, n.1, p.76-85, 2019. http://dx.doi.org/10.1590/2317-1545v41n1212109

LAMARCA, E.V.; OLIVEIRA-JUNIOR, C.J.F.; BARBEDO, C.J. Etnobotânica na conservação de espécies com sementes sensíveis à dessecação: o exemplo da Eugenia brasiliensis Lam. Hoehnea, v.47, e372019, 2020. https://doi.org/10.1590/2236-8906-37/2019

LEGRAND, C.D.; KLEIN, R.M. Mirtáceas: Eugenia. In: Reitz R. Flora Ilustrada Catarinense. Itajaí: Herbário Barbosa, 1969. p.45-216.

MALUF, A.M.; BILIA, D.A.C.; BARBEDO, C.J. Drying and storage of Eugenia involucrata DC. seeds. Scientia Agricola, v.60, n.3, p.471475, 2003. https://doi.org/10.1590/S0103-90162003000300009

MARCOS-FILHO, J. Fisiologia de sementes de plantas cultivadas. Londrina: ABRATES, 2015. 659p.

MASETTO, T.E.; FARIA, J.M.R.; DAVIDE, A.C.; SILVA, E.A.A. Desiccation tolerance and DNA integrity in Eugenia pleurantha O. Berg. (Myrtaceae) seeds. Revista Brasileira de Sementes, v.30, n.1, p.175-180, 2008. http://dx.doi.org/10.1590/S010131222008000100022

MCLAREN, K.P.; MCDONALD, M.A. The effects of moisture and shade on seed germination and seedling survival in a tropical dry forest in Jamaica. Forest Ecology and Management, v.183, n.1-3, p.61-75, 2003. https://doi.org/10.1016/S0378-1127(03)00100-2

MICHEL, B.E.; KAUFMANN, M.R. The osmotic potential of polyethylene glycol 6000. Plant Physiology, v.51, n.5, p.914-916, 1973. https://doi.org/10.1104/pp.51.5.914

PAMMENTER, N.W.; BERJAK, P.; FARRANT, J.M.; SMITH, M.T.; ROSS, G. Why do stored hydrated recalcitrant seeds die? Seed Science Research, v.4, n.2, p.187-191, 1994. https://doi.org/10.1017/S0960258500002178

SANTANA, D.G.; RANAL, M.A. Análise da germinação: um enfoque estatístico. Brasília: UnB, 2004. 247p.

SCALON, S.P.Q.; NEVES, E.M.S.; MASETO, T.E.; PEREIRA, Z.V. Sensibilidade à dessecação e ao armazenamento em sementes de Eugenia pyriformis Cambess. (uvaia). Revista Brasileira de Fruticultura, v.34, n.1, p.269-276, 2012. https://doi.org/10.1590/S010029452012000100036

SILVA, C.V.; BILIA, D.A.C.; BARBEDO, C.J. Fracionamento e germinação de sementes de Eugenia. Revista Brasileira de Sementes, v.27, n.1, p.86-92, 2005. https://doi.org/10.1590/S0101-31222005000100011

SILVA, L.A.; SALES, J.F.; SANTOS, H.O.; MARTINS, J.M.; COSTA, V.H.; SILVA, F.G. Physiological performance of cagaita seeds (Eugenia dysenterica DC.) subjected to drying. Semina: Ciências Agrárias, v.38, n.1, p.19-34, 2017. http://dx.doi.org/10.5433/16790359.2017v38n1p19 
TEIXEIRA, C.C.; BARBEDO, C.J. The development of seedlings from fragments of monoembryonic seeds as an important survival strategy for Eugenia (Myrtaceae) tree species. Trees, Structure and Function, v.26, n.3, p.1069-1077, 2012. https://doi.org/10.1007/ s00468-011-0648-5

UMARANI, R.; AADHAVAN, E.K.; FAISAL, M.M. Understanding poor storage potential of recalcitrant seeds. Current Science, v.108, n.11, p.2023-2034, 2015. http://www.jstor.org/stable/2490557103 use, distribution, and reproduction in any medium, provided the original work is properly cited. 